\title{
Reflections on Self-Reflection: A Course-Based Qualitative Inquiry into the Self-Reflective Practice of Child and Youth Care Students
}

\author{
Janelle Huhtala, BCYC \\ Janaya Hewitt, $B C Y C$ \\ Shayla Wood, BCYC \\ Tannis Bassett, BCYC \\ Sheharra Kanagasuriam, BCYC \\ MacEwan University, Alberta, Canada \\ Gerard Bellefeuille \\ Professor \\ Department of Child and Youth Care \\ MacEwan University, Alberta, Canada
}

\begin{abstract}
Self-reflection is a skill that is central to child and youth care (CYC) students' professional development. Due to itsimportance and the role in CYC practice, it is important to know how self-reflection is regarded and practiced by CYC students in their field placements. The aim of this study is to investigatethe frequency, form, and meaning of selfreflection from the perspective of CYC students to gain insight into how CYC students apply the concept in their practice. Data are collected through semi-structured focus groups and an arts-based activity. From the data analysis, four main themes are extracted: (a) the importance of relationships, (b) a form of self-care, $(c)$ time is required, and $(d)$ a pathway to better practice. The findings reveal that despite the value placed on reflective practice in CYC education, there is a lack of research on the form that it takes in the practice (if it is practiced at all)of students in practicum placements.
\end{abstract}

Keywords: child and youth care, course-based, self-reflection, qualitative.

\section{Introduction}

Over the course of afour-year CYCprogram of study,studentsare required to complete three separate field placements. These placements occur in the first, second, and fourth-year, and occur in very diverse,multifaceted, and ever-changing practical contexts. One of the essential skills that CYC students are taught isthe art of critical self-reflection. Although there are numerous definitions ofself-reflective practice with no overall consensus, there are some commonalities in the literature on the nature ofself-reflective practice. In general, self-reflective practice is possibly best understood as the capacity to reflect on one's thoughts, emotions, and actions so as to engage in a process of continuous personal and professional learning (Fook \& Askeland, 2006; Schon, 1996; Taylor, 2000). As Stringer (1996) asserted, when practitioners "reflect on their situation, they can conceive solutions to their problems with a degree of clarity that escapes them in the rush and clutter of their day-to-day lives" (p.97). The reason for the emphasis on self-reflection as a core competency for helping professionals is that it promotes the lifelong practice of self-discovery and growth, as well as the expansion of one's knowledge (Bandura, 1986; Boud, Keogh, \& Walker, 1985; Epstein, 1999).As Mann, Gordon, and MacLeod (2009) explained, self-reflection can occur in real-time (i.e., reflection in action) or retrospectively (reflectiononaction). Self-reflection plays a pivotal role in CYC work because CYC practitioners must not only be self-aware of their relational skills, theoretical beliefs,communication style, and emotional presence but must also be responsive to the diverse uniqueness of others (Bellefeuille et al., 2017).Collins and Arthure (2010), for example, discussedthe ways in which ethnocentric or cultural-centric thinking (i.e., one's unconscious personal biases, judgments, and assumptions) can impact decision-making and the formation of positive relationships. Finally, selfreflection is a dynamic process of self-analysis, self-evaluation, self-dialogue, and self-observation (Thomlinson, Thomlinson, Peden-McAlpine \& Kirschbaum, 2002). As such, self-reflection is at the heart of becoming a competent and confident CYC practitioner. However, while reflective practice has been widely researched across a variety of helping professions, limitedevidence-based research has been conducted within the context of CYCpractice. 
For example, little is known about the form that self-reflection actually takes for CYC students in field placements. The failure to assess CYC students' adeptness in self-reflective practice can result in insufficient guidance for CYC educators to foster critical self-reflective capabilities. Therefore, the purpose of this course-based research project is to investigate the frequency, form, and meaning of self-reflection from the perspective of CYC students to gain insight into how these students apply the concept in their practice.

\section{Undergraduate Course-Based Research: A Pedagogical Tool Used to Foster Criticality, Reflectivity, and Praxis}

The Bachelor of Child and Youth Care program at MacEwan University is continuously searching for new pedagogical approaches to foster criticality, reflectivity, and praxis, all of which the program considers integral components of the overall student educational experience. As such, the design and implementation of a course-based approach, in contrast with the traditional didactic approach to research-methods instruction, offers fourth-year undergraduate students the opportunity to master introductory research skills by conceptualizing, designing, administering, and showcasing small, minimum-risk research projects under the guidance and supervision of the course instructor (commonly, a professor with an extensive background in research and teaching).

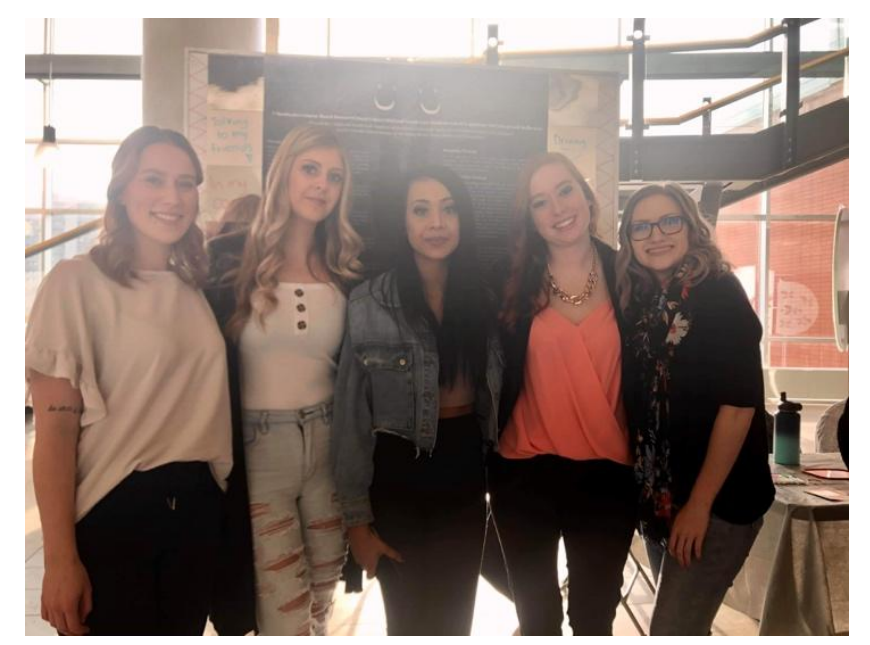

(From left to rightJanaya Hewitt, Shayla Wood, SheharraKanagasuriam, Tannis Bassett, Janelle Huhtala

The use of course-based research in higher education has increased substantially in recent years (Allyn, 2013; Bellefeuille, Ekdahl, Kent, \&Kluczny, 2014; Harrison, Dunbar, Ratmansky, Boyd, \&Lopatto, 2010). The benefits derived from a course-based approach to teaching research methods for CYC students are significant. First, there is value in providing students with authentic learning experiences that enhance the transfer of knowledge learned in traditional education practice. For example, former students have reported that their engagement in course-based research enabled them to deepen their scientific knowledge by adopting new methods of creative inquiry. Second, course-based research offers students the opportunity to work with instructors in a mentoring relationship; one result is that a greater number of student's express interest in advancing to graduate studies. Third, results generated through course-based research can sometimes be published in peer-reviewed journals and online open-access portals and thereby contribute to the discipline's knowledge base.

The ethical approval required to permit students to conduct course-based research projects is granted to the course instructor by the university's research ethics board (REB). Student research groups are then required to complete an REB application form for each course-based research project undertaken in the class; each application is then reviewed by the course instructor and a sub-REB committee to ensure each course-based research project is completed and is in compliance with the ethics review requirements of the university.

\section{Research Design}

Because self-reflection cannot be measured in any systematic way (Ward \&McCotter, 2004) and is not governed by rules or a standardized process (Schon, 1996), it can best be understood through experience with it. Hence, this coursebased research studywas founded on a qualitative approach to inquiry and adopted an interpretivist philosophical position focused primarily on the experience and understandings within a student's world. According to Creswell (2013),the interpretive paradigm allows researchers to view the world through the perceptions and experiences of the participants. As Willis (2007) explained, the core belief of the interpretive paradigm is that reality is socially constructed. 
As a result, supporters of interpretivism neitherbelieve in the actuality of universal standards for researchnor seek the answers to their investigations in rigid ways (Denzin and Lincoln, 2000). Expounding on this notion, Smith (1993) argued that"there is no particular right or correct path to knowledge, no special method that automatically leads to intellectual progress" (p.120). There is a close connection between the interpretivist paradigm and qualitative methodology (Creswell, 2013). Schwandt (2000) assertedthat qualitative research is a holistic approach to discovery and that qualitative data collection methodscan be used to capture in-depth information about a phenomenon.

\section{Sampling Strategy}

A non-probability, expert sampling strategy was used to identify participants for this course-based study. A core characteristic of non-probability sampling techniques is that sampling is not a product of randomized selection processes (Patton, 2002). It is a highly subjective method that is based on the nature and purpose of the study, which areused to decide the elements that are included in the sample (Battaglia, 2008). Hence, non-probability sampling is the deliberate choice of a participant due to the qualities that the participant possesses.

\section{Statement of Research Question}

The following research question guided the inquiry: How do the CYC students at MacEwan University apply selfreflection in their CYC practice?

\section{Data Collection}

Two separate data collection strategies were used to collect the data for this course-based study. As a research strategy,data collection triangulation represents the use of multiple methods or data sources in qualitative research to enrich a thorough understanding of phenomena (Patton, 2002). Data collection triangulation is also used as a qualitative research strategy to increasemethodological rigor through the convergence of information from different sources (Polit \& Beck, 2012).

\section{Semi-Structured Focus Group}

Firstly, a semi-structured focus group was chosen as the primary means of data collection because this method commonly yields meaningful opinions, suggestions, and feedback when used to explore participants' subjective experiences (Krueger \& Casey, 2000). Similarly,Stewart, Shamdasani, and Rook (2007)asserted that the focus group data collection method can not only be used to acquire new knowledge but also to seek opinions, values, and beliefs in a collective context. Furthermore,Barbour and Kitzinger (1999) suggested that focus groups are an ideal method for exploring participants' experiences, opinions, wishes, and concerns because thegroup dynamic can aid participants in expressing andclarifying their views in ways that are less likely tooccur in one-on-one interviews. Therefore, two separate focus group discussions were facilitated among third-year and fourth-year CYC students.

\section{Expressive Arts-Based Method}

Secondly, an expressive arts-based method was used to explore how participants felt about their participation in the focus group as a self-reflective activity. Each participant was presented with a handheld mirror, whiteboard markers, and paper towels. The participants were then invited to draw or write about how they felt about having participated in a reflective focus group about their self-reflective practice. A photograph was taken of their creations. The participants were then invited to draw or write about how they felt before participating in the reflective focus group and how that may have differed to what they felt following the focus group discussion. This activity provided data about the potential impact of self-reflection.

Arts-based research methods are considered to be"any social research or human inquiry that adapts the tenets of the creative arts as a part of the methodology [...] during data collection, analysis, interpretation and/or dissemination" (Jones \&Leavy, 2004, pp.1-2). As Franz (2010) explained, arts-based research has many facets, representing the large variety of art genres, such as performance, writing, painting, photography, collage, and thevisual arts. Finally, McNiff (2007) defined art-based research:

as the systematic use of the artistic process, the actual making of artistic expressions in all of the different forms of the arts, as a primary way of understanding and examining experience by both researchers and the people that they involve in their studies. (p. 29)

\section{Data Analysis Methodology}

Data wereanalyzed using Braun and Clarke's (2006) six stages of thematic analysis techniques: (1) familiarizing oneself with the data, (2) generating initial codes, (3) searching for themes, (4) reviewing and refining themes, (5) defining and naming themes, and (6) producing a report. From the data analysis, four main themes were extracted: (a) the importance of relationships, (b) a form of self-care, (c) time is required, and (d) a pathway to better practice. 


\section{Importance of Relationships}

Participants stressed the importance of having a meaningful relationship with a supervisor or colleague as a contributingfactorin facilitating their self-reflection. They expressed a belief that self-reflection is easier with the relational support of a colleague. For example, one participant noted that"reflection is easier with a close colleague than with a supervisor you see only once a month." Another participant stated that "it is harder to reflect as an employee than as a practicum student because supervisors tend to be more involved witha practicum student."The participants also held the common opinion that they preferred to reflect with others who worked in the same field (i.e., working with children and young people). According to the participants, self-reflecting with a family or friend felt too much like venting, noting thatself-reflecting on how a day went with a family or friend would elicit responses such as "sounds like you had a bad day."

\section{A Form of Self-Care}

A second dominant theme was the way in which participants viewed self-reflection as an integral self-care strategy. One participant, for example, stated, "I use self-reflection as a form of self-care because it relieves guilt and reminds them that I am doing good work".Another participant commented that "the more I reflect, I realize that the work I do is reallymeaningful." Other statements included"Byreflecting, you are letting it go in a way where you will be conscious of it if something similar happens" and"reflection gives meaning to a negative situation.

\section{Time is Required}

Many of the participants talked about the importance of finding the time to self-reflect. A shared observation was that time for self-reflection is not built into the workplace. Participants noted that shift exchange is brief, and the conversation is focused on job duties, such as when the children or young people last ate andwhetherthe children or young people have received their medications.Participants also stated that practitioners do not tend to use shift exchange to discuss how the team thought the day went or to discuss goals and ideas for the next shift. For example, one participant said, "I often work with other relief staff who are not familiar with the group home or children/young people living there so they are not able or willing to have reflective conversations." Another participant said, "I felt a hierarchy of full-time versus relief staff and felt as though the full-time staff did not deem reflecting with relief staff to be worth their time." Additional comments included that "it is difficult to reflect if the other practitioners you are working with are working just to get paid and do not have any passion for the job" and "when I attempt to reflect on why a staff member responded in a certain way, I often get responses of 'this is just how we do it."”

\section{A Pathway to Better Practice}

The final theme was the recognition that self-reflection leads to better practice. Participants said that their passion to become better practitioners is part of what motivates them to reflect:"How do I want to go forward to do what I want to practice and be the worker I want to be and what would have to change?"Other participants talked about how selfreflection helps them to develop andchallenge themselves whileoffering new insights and perspectives: "Everything is so individual, so you really genuinely need to figure out what works for you because it is foundational - it is integral you can't function as a worker in any helping field if you are not reflecting."

\section{Conclusion}

Despite the value that is placed on reflective practice in CYC education, there is a lack of research on the form that it takes in the practice (if it is practiced at all)of students in practicum placements. This course-based research study provided a glimpse into the ways in which CYC students understand, practice, and value the importance of selfreflection. An important finding was that although CYC students are taught the importance of self-reflection in the classroom, they generally struggle to engage in self-reflective practice in their practicum placements due to a combination of factors. These include a reported lack of support from their supervisors, not finding or making the time to self-reflect, and, to some degree, a lack of awareness of how to self-reflect. The findings have implications for CYC education and practice. CYC instructors can make use of these findings to promote more discussion and practice of self-reflective skills. Students in practicum placements could be asked to document how they are self-reflecting on a daily basis to assess their proficiency in practicing the skill and to correct deficiencies in real-time. Finally, in view of the need to conduct more research in this area, it is hoped that further investigation will take place at the faculty level or in future student-led course-based research projects. 


\section{References}

Allyn, D. A. (2013). Course-based undergraduate research: It can be accomplished! Journal of Physical Education, Recreation \& Dance, 84(9), 32-36.

Barbour, R. S., \& Kitzinger, J. (Eds.). (1999). Developing focus group research: Politics, theory and practice. Sage Publications Ltd.

Battaglia, M. P. (2008). Non probability sampling. Encyclopedia of survey research methods. Sage Publications 1-4.

Bellefeuille, G., Ekdahl, C., Kent, L., \&Kluczny, M. (2014). A course-based creative inquiry approach to teaching introductory research methods in Child and Youth Care undergraduate education. International Journal of Teaching and Education, 2(2), 1-9.

Bellefeuille, G., Stiller, B., Neuman, S., Deol, J., Smith, C., Brown, M., Gautreau, \&Diduch, A. (2017). Building a child and youth care culture of relational-centred praxis: Ours to make. American Journal of Education and Learning, 2(1), 43-64.

Bandura, A. (1986). Social foundations of thought and action: A social cognitive theory. Englewood Cliffs, NJ: Prentice Hall.

Boud, D., Keogh, R., \& Walker, D. (Eds) (1985). Reflection: Turning experience into learning. London: Kogan Page.

Braun, V.\& Clarke, V. (2006). Using thematic analysis in psychology. Qualitative Research in Psychology, 3(2), 77101.

Collins, S., \& Arthur, N. (2010). Self-awareness and awareness of client cultural identities. In N. Arthur \& S. Collins (Eds.), Culture-infused counselling (pp. 67-102). Calgary, Alberta, Canada: Counselling Concepts.

Creswell, J. W. (2013). Qualitative inquiry and research design: Choosing among five approaches (3rd ed.) CA: Sage: Thousand Oaks.

Denzin N. and Lincoln Y. (Eds.) (2000). Handbook of qualitative research. London: Sage Publication Inc.

Epstein, R. M. (1999). Mindful practice. Journal of the American Medical Association, 282, 833-839.

Fook, J., \&Askeland, G. A. (2006). Challenges of critical reflection: Nothing ventured, nothing gained. Social Work Education,16,(2)1-14.

Franz, Jill M. (2010). Arts-based research for teachers, researchers and supervisors. Brisbane: Queensland University of Technology.

Harrison, M., Dunbar, D., Ratmansky, L., Boyd, K., \&Lopatto, D. (2010). Classroom-based science research at the introductory level: Changes in career choices and attitude. CBE Life Sciences Education, 10(3), 279-86.

Jones, K.,\&Leavy, P. (2014). A conversation between Kip Jones and Patricia Leavy: Arts-based research, performative social science and working on the margins. The Qualitative Report, 19(38), 1-7.

Krueger, R. A., \& Casey, M. A. (2000). Focus groups: A practical guide for applied research, (4th ed.). Thousand Oaks, CA: Sage Publications Inc.

Mann, K., Gordon, J., \& MacLeod, A. (2009). Reflection and reflective practice in health professions education: A systematic review. Advances in Health Sciences Education, 14, 595-621.

McNiff, S. (2007). Arts-based research. In J. G. Knowles \& A. L. Cole (Eds.), Handbook of the arts in qualitative research(pp. 29-40). Thousand Oaks, CA: AltaMira Press.

Patton, M. Q. (2002). Qualitative research and evaluation methods (3rd. ed.). Thousand Oaks, CA: Sage.

Polit, D.F., \& Beck, C.T. (2012). Nursing research: Generating and assessing evidence for nursing practice (9th. ed.). Thousand Oaks, CA: Sage.

Schön, D. A. (1996). Educating the reflective practitioner: Toward a new design for teaching and learning in the professions. San Francisco: Jossey-Bass.

Schwandt, T.A. ( 2000). Three epistemological stances for qualitative inquiry: Interpretivism, hermeneutics and social constructivism. In N. K. Denzin \& Y. S. Lincoln (Eds.), Handbook of qualitative research (2nd ed.)(pp. 189214). Thousand Oaks, CA: Sage.

Smith, J. (1993). After the demise of empiricism: The problem of judging social and educational inquiry. New York: Ablex.

Stewart, D. W., Shamdasani, P. N., \& Rook, D. W. (2007). Focus groups: Theory and practice. Thousand Oaks, CA: Sage Publications Inc.

Stringer, E. T. (1996). Action research: A handbook for practitioners. Thousand Oaks, CA: Sage.

Taylor, B. (2000) Reflective practice. Buckingham: Open University Press.

Tomlinson, P. S., Thomlinson, E., Peden-McAlpine, C., \&Kirschbaum, M. (2002). Clinical innovation for promoting family care in paediatric intensive care: Demonstration, role modelling and reflective practice. Journal of Advanced Nursing, 38(2), 1-10. 
Tomlinson, P. S., Thomlinson, E., Peden-McAlpine, C., \&Kirschbaum, M. (2002). Clinical innovation for promoting family care in paediatric intensive care: Demonstration, role modelling and reflective practice. Journal of Advanced Nursing, 38(2), 1-10.

Tomlinson, P. S., Thomlinson, E., Peden-McAlpine, C., \&Kirschbaum, M. (2002). Clinical innovation for promoting family care in paediatric intensive care: Demonstration, role modelling and reflective practice. Journal of Advanced Nursing, 38(2), 1-10.

Ward, J., \&McCotter, S. (2004). Reflections a visible outcome for preservice teachers. Teaching and Teacher Education, 20, 243-257.

Willis, J. W. (2007). Foundations of qualitative research: interpretive and critical approaches. London: Sage. 